\title{
Microbiological quality of silage made from by-products of cassava starch extraction and viticulture
}

\author{
C.R. Schneider ${ }^{1 \#}$, M.A. Zambom ${ }^{1}$, D. Galhardo ${ }^{1}$, A. Faccenda ${ }^{2}$, A.S. Avila ${ }^{1}$, R.C.R. Tinini ${ }^{3}$ \& \\ T.A. Del Valle ${ }^{4}$ \\ ${ }^{1}$ State University of Western Parana, Marechal Candido Rondon, Brazil \\ ${ }^{2}$ State University of Maringa, Maringa, Brazil \\ ${ }^{3}$ Uniguaçu, Sao Miguel do Iguaçu, Brazil \\ ${ }^{4}$ Federal University of Pampa, Itaqui, Brazil
}

(Received 1 April 2020; Accepted 14 April 2021; Published 30 June 2021)

\begin{abstract}
Copyright resides with the authors in terms of the Creative Commons Attribution 4.0 South African Licence. See: http://creativecommons.org/licenses/by/4.0/za

Condition of use: The user may copy, distribute, transmit and adapt the work, but must recognise the authors and the South African Journal of Animal Science.
\end{abstract}

\begin{abstract}
This study evaluated silages made with varying proportions of viticulture by-products (VC) and starch extraction from cassava (CSE). It attempted to determine the effects of these proportions on the microbial population, fermentative losses, and chemical composition. The treatments were specified as the proportions of VC in the silage $(0 \mathrm{~g} / \mathrm{kg}, 250 \mathrm{~g} / \mathrm{kg}, 500 \mathrm{~g} / \mathrm{kg}, 750 \mathrm{~g} / \mathrm{kg}$, and $1000 \mathrm{~g} / \mathrm{kg})$. Silages were evaluated before (0) and after $1,3,7,15,30$, and 60 days of ensiling. The experimental design was completely randomized with five treatments, six storage times and four replications. The increased level of VC in the silage enhanced its dry matter content, ammonia nitrogen $\left(\mathrm{NH}_{3}-\mathrm{N}\right)$, and buffering capacity, and reduced organic matter content. Fifteen days after ensiling, additional VC increased the concentration of soluble carbohydrates. The increased level of VC decreased the count of Clostridium spp. and lactic acid bacteria (LAB). The incidence of yeasts and enterobacteria was low in all treatments at all time points. Over time, losses as effluent and gases increased. Use of increasing proportions from VC in silage made with CSE increased the contents of dry matter and soluble carbohydrates and reduced the fermentative losses of the silage. The increased amount of $\mathrm{VC}$ also favoured $\mathrm{pH}$ reduction and reduced the proliferation of undesirable yeasts, while increasing the population of $L A B$.
\end{abstract}

Keywords: by-products, enterobacteria, lactic acid bacteria, microbial population \#Corresponding author: cibeleregina17@hotmail.com

\section{Introduction}

Use of agro-industrial by-products in animal feed can reduce production costs. Cassava roots are widely used as a source of starch in regions where it is grown. The by-product of cassava starch extraction (CSE) is used in feeding livestock in these regions, such as in southern Brazil (Gonçalves et al., 2014; Zambom et al., 2014; Zambom et al., 2015). However, because the dry matter content of cassava by-product is low (average $150 \mathrm{~g} / \mathrm{kg}$ ) (Jasko et al., 2011), its on-farm preservation and storage can be challenging.

Viticulture by-product, which is obtained from pressing grapes in wineries, is composed of bagasse and seeds (Kalli et al., 2018). Disposal of this by-product presents a consequential environmental impact and increases the cost of wine production (Correddu et al., 2015). Thus, it is essential to find alternatives for its use (Čolović et al., 2019). One such alternative is in feeding livestock. It has a DM content of approximately $337 \mathrm{~g} / \mathrm{kg}$ and a pH of around 4.11 (Santos et al., 2014). Owing to the low pH, VC inhibits the growth of undesirable microorganisms, such as bacteria of the genus Clostridium, and enterobacteria, and fungi and yeasts. The VC can be used as an alternative feed in regions with greater availability, reducing the effects of seasonality on forage production and production costs (Santos, 2014; Čolović et al., 2019).

Cassava starch extraction and VC can both be used in the fresh form for animal feeding. However, they do not maintain nutritional quality for long. Thus it is necessary to process them by drying or ensiling to conserve them for use as a feedstuff (Javorski et al., 2015; Fernandes et al., 2016; Massaro Junior et al., 2020). However, information on the characterization and use of VC as silage is scarce (Ke et al., 2015). Thus, it was hypothesized that the addition of VC to CSE as a product for silage making could reduce the 
proliferation of undesirable microorganisms, minimize fermentative losses, improve the chemical composition of silage, and reduce the time for silage stabilization. Effects of various proportions of CSE and VC in silage on the microbial population, fermentative losses, and chemical composition of silage were evaluated over a 60-day period after ensiling.

\section{Material and Methods}

The experiment was performed at the State University of Western Parana $\left(24^{\circ} 33^{\prime} 27.5\right.$ "S and $\left.54^{\circ} 02^{\prime} 56.2^{\prime \prime} \mathrm{W}\right)$ located in the state of Paraná, Brazil. The CSE was obtained from industry and the VC was obtained from a winery, both from the western region of Paraná State, Brazil.

Extraction of the cassava starch used the wet processing method. Initially, cassava roots were washed, peeled and ground. Then the material was placed in tanks with agitators and sieves for starch extraction. The liquid slurry was decanted to obtain the starch (Sebrae, 2008). The by-product residue was obtained by filtration. Because fermentation occurred, this by-product had a $\mathrm{pH}$ of 4.05 when it was obtained from the industry. The chemical composition of the CSE was $131 \mathrm{~g} / \mathrm{kg} \mathrm{DM}, 975 \mathrm{~g} / \mathrm{kg}$ organic matter (OM), $17.9 \mathrm{~g} / \mathrm{kg}$ crude protein (CP), $8.0 \mathrm{~g} / \mathrm{kg}$ ether extract (EE), $471 \mathrm{~g} / \mathrm{kg}$ neutral detergent fibre (NDF), $313 \mathrm{~g} / \mathrm{kg}$ acid detergent fibre (ADF), and $103 \mathrm{~g} / \mathrm{kg}$ lignin.

The grapes were processed by first removing the stems, which were discarded, then pressed to break the skin and release the juice, which was subsequently fermented to transform the sugar into alcohol. This process was carried out in stainless steel tanks at a temperature between $25^{\circ} \mathrm{C}$ and $30{ }^{\circ} \mathrm{C}$ over two to five days. Subsequently, the VC was removed. The $\mathrm{pH}$ of the viticulture residue was 3.45 , and its chemical composition was $390 \mathrm{~g} / \mathrm{kg}$ DM, $945 \mathrm{~g} / \mathrm{kg} \mathrm{OM}, 121 \mathrm{~g} / \mathrm{kg} \mathrm{CP}, 85.8 \mathrm{~g} / \mathrm{kg} \mathrm{EE}, 582 \mathrm{~g} / \mathrm{kg} \mathrm{NDF}, 510 \mathrm{~g} / \mathrm{kg} \mathrm{ADF}$, and $139 \mathrm{~g} / \mathrm{kg}$ lignin.

The materials were mixed in these proportions, namely $0 \%$ VC and $100 \%$ CSE, $25 \%$ VC and $75 \%$ CSE, $50 \%$ VC and $50 \%$ CSE, $75 \%$ VC and $25 \%$ CSE, and $100 \%$ VC and $0 \%$ CSE. The mixtures were homogenized and ensiled in silos that were made of polyvinyl chloride pipe, $10 \mathrm{~cm}$ in diameter and $50 \mathrm{~cm}$ in height, with a Bunsen-type valve that allowed gas to escape. The specific mass of the ensiled material was $891,877,900,882$, and $832 \mathrm{~kg}$ as-fed $/ \mathrm{m}^{3}$ for silages with $0 \%, 25 \%, 50 \%, 75 \%$, and $100 \% \mathrm{VC}$, respectively.

A layer of autoclaved and dried sand $(0.5 \mathrm{~kg})$ was placed in the bottom of each silo and covered with a layer of cotton cloth, to drain possible effluents and to avoid contact between the sand and the silage. The experimental silos were stored at room temperature under protection from sunlight until they were opened. When a silo was opened, a $5-\mathrm{cm}$ layer of silage was discarded from the top and bottom and the remaining material was homogenized and sampled. The silages were evaluated before ensiling on days 0 and 1, 3, 7, 15,30 and 60 days after ensiling. Thus, the experimental design was completely randomized with five treatments, six storage times and four replications.

Samples were pre-dried in a forced air oven at $55^{\circ} \mathrm{C}$ for 72 hours and ground in a Willey mill (STAR FT 60, FORTINOX, São Paulo, Brazil) with a $1 \mathrm{~mm}$ sieve, and analysed for DM (method 930.15, AOAC 2000) and ash (method 942.05, AOAC 2000). Organic matter content was calculated as OM = 100 - ash (\%). Dry matter recovery, and losses by gases and effluents were determined using equations described by Jobim et al. (2007):

$$
D M R=\left(\frac{F M o \times D M o}{F M S \times D M S}\right) \times 100
$$

where: $\mathrm{DMR}=$ dry matter recovery $(\%)$,

$\mathrm{FMo}=$ forage mass at the opening $(\mathrm{kg})$,

$\mathrm{DMo}=\mathrm{DM}$ content at the opening (\%),

FMs $=$ initial forage mass of the silage $(\mathrm{kg})$, and

DMs = initial DM content of the ensiled forage (\%).

$$
G L=\left(\frac{S W s-P S o}{F M s \times D M S}\right) \times 100
$$

where: $\mathrm{GL}=$ gas losses (\% of initial DM),

SWs = silo weight at ensiling ( $\mathrm{kg}$ of wet weight),

PSo $=$ silo weight at the opening ( $\mathrm{kg}$ of as-fed),

$\mathrm{FMs}=$ initial forage mass of the silage $(\mathrm{kg})$, and

DMs = initial DM content of the ensiled forage (\%). 


$$
E P=\left(\frac{W o-S w}{G W e f}\right) \times 1000
$$

where: $E P=$ effluent production $(\%)$,

Wo $=$ weight of the set $($ silo + cover + wet sand + fabric) at opening $(\mathrm{kg})$,

$\mathrm{Sw}=$ set weight set at ensiling $(\mathrm{kg})$, and

GWef $=$ green weight of ensiled forage $(\mathrm{kg})$.

To determine $\mathrm{NH}_{3}-\mathrm{N}, 200 \mathrm{~g}$ of each sample was pressed in a hydraulic press (P15 ST, BOVENAU, São José do Rio Preto, Brazil). The extract was centrifuged at 3000 revolutions per minute for 15 minutes with the supernatant being analysed by the distillation method with potassium hydroxide according to Fenner (1965).

On opening of a silo, the temperature was measured with a skewer-type thermometer. The $\mathrm{pH}$ was measured with a digital $\mathrm{pH}$ meter (Tec 2-mp Tecnal, Tecnal Scientific Equipment, Piracicaba, Brazil) by adding $100 \mathrm{~mL}$ of distilled water to $10 \mathrm{~g}$ of sample and allowing the mixture to rest for one hour before reading, according to Cherney and Cherney (2003). Room temperature was 27.0; 23.2; 21.0; 25.8; 24.5; 25.4 , and $23.2{ }^{\circ} \mathrm{C}$ at $0,1,3,7,15,30$, and 60 days of storage, respectively.

Buffering capacity was determined according to Playne and McDonald (1966). Approximately $15 \mathrm{~g}$ of the material was macerated before ensiling and then diluted in $250 \mathrm{~mL}$ of distilled water, titrated to $\mathrm{pH} 3.0$ with hydrochloric acid $(0.1 \mathrm{~N})$, and subsequently titrated with sodium hydroxide $(0.1 \mathrm{~N})$ to $\mathrm{pH}$ 6.0.

Water-soluble carbohydrates (WSC) were determined using glucose as a standard (Dubois et al., 1956). Two hundred $\mathrm{mg}$ of the crushed sample was weighed into a $250 \mathrm{~mL}$ Erlenmeyer flask and $200 \mathrm{~mL}$ of distilled water was added. The flasks were then placed in an incubator with an orbital shaking table at 200 rotations per minute and held at room temperature for one hour to dissolve the sugars. After dissolving the sugars in water, the contents were filtered on quantitative filter paper with rapid filtration, retaining approximately $50 \mathrm{~mL}$ of the filtered liquid. Subsequently, a $0.5 \mathrm{ml}$ aliquot was placed in a test tube, and 0.5 $\mathrm{ml}$ of $5 \%$ phenol and $2.5 \mathrm{~mL}$ of sulfuric acid were added, and this tube was immersed in a water and ice bath for 10 minutes. After cooling, slight agitation was applied and light transmission was read with a spectrophotometer (UV-1800, Shimadzu Corporation, Kyoto, Japan) at $490 \mathrm{~nm}$.

Microbial populations were determined with one homogenized sample from each silo. Culture techniques were performed according to Silva et al. (1997) adding sterile distilled water $(225 \mathrm{~mL})$ to $25 \mathrm{~g}$ of sample while stirring. From this solution, $1 \mathrm{~mL}$ was pipetted in successive dilutions of $10^{-1}$ to $10^{-5}$, using test tubes containing $9 \mathrm{~mL}$ of sterile distilled water. Subsequently, from the diluted extracts, petri dishes were sown on the surface using $0.1 \mathrm{~mL}$ of inoculum per plate and $1 \mathrm{~mL}$ for plates sown in depth. To count the enterobacteria, samples were seeded in-depth on plates with violet red bile agar (VRB) and kept under incubation at $35^{\circ} \mathrm{C}$ for 24 hours. For analysis of Clostridium spp., samples were sown on the surface in petri dishes with reinforced clostridial agar (RCA) maintained under anaerobic incubation in an oven with a $\mathrm{CO}_{2}$ gas system at $35^{\circ} \mathrm{C}$ for 24 hours. The LAB were sown on deMan, Rogosa and Sharpe (MRS) agar and incubated for 48 hours in an oven at $37^{\circ} \mathrm{C}$. After incubation, the bacteria population was counted in a Quebec colony counter (CP 608, Phoenix Luferco, Araraquara, Brazil) and transformed to $\log _{10}$ in as-fed.

Data were analysed using the PROC MIXED of SAS version 9.3 (SAS Institute Inc., Cary, North Carolina, USA). The linear model was:

$$
Y_{i j k}=\mu+V C_{i}+T_{j}+V C \times T_{i j}+e_{i j k}
$$

where: $Y_{i j k}=$ dependent variable,

$\mu=$ general mean,

$V C_{i}=$ fixed effect of the level of $\mathrm{VC}(i=1$ to 5$)$,

$T_{j}=$ fixed effect of the storage time of the experimental silos $(j=1$ to 6 for fermentative losses and

1 to 7 for other variables),

$V C \times T_{i j}=$ interaction effect, and

$e_{i j k}=$ random residual error.

The errors were assumed to be normally distributed about mean 0 with a common variance denoted as $\sigma_{e}^{2}$. In the analysis of buffering capacity, the effects $T_{j}$ and $V C \times T_{i j}$ were removed from the model. The effects of treatments were further studied using orthogonal contrasts to assess the linear and quadratic effects. A significance level of $5 \%$ was used for all analyses. 


\section{Results and Discussion}

The addition of VC increased $(P<0.001)$ the DM content of the silage linearly (Table 1$)$ regardless of

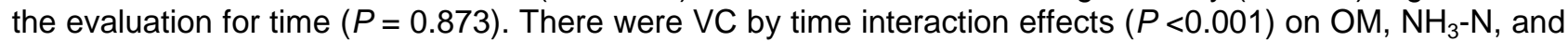
WSC concentration. The effect of VC level was to decrease $\mathrm{OM}$ at a decreasing rate over time. This decrease became slightly smaller as the samples were ensiled for longer.

Except for the first day after ensiling $(P=0.273)$, there was a quadratic effect $(P<0.001)$ of VC levels on the silage $\mathrm{NH}_{3}-\mathrm{N}$ concentration. This effect was owing to an increase of $\mathrm{NH}_{3}-\mathrm{N}$ until $75 \% \mathrm{VC}$, with a reduction in $\mathrm{NH}_{3}-\mathrm{N}$ concentration in the silages composed of $100 \%$ VC. In general, there were linear $(P=$ $0.010)$ and quadratic $(P=0.049)$ effects of VC levels on the WSC concentration. The WSC concentration typically increased following ensiling, reached a maximum, and then decreased with time. The maximum was observed somewhat later after ensiling in the silages that contained more VC.

There was a treatment and storage time interaction $(P<0.001)$ effect on enterobacteria count, $\mathrm{pH}$, and temperature of silage (Table 2). Clostridium spp. and LAB counts decreased linearly $(P \leq 0.016)$ with the increased level of VC. The VC did not affect $(P=0.569)$ the yeast population and VC linearly decreased $(P=$ $0.008)$ silage buffer capacity.

There was an interaction between time and treatment effects $(P=0.004)$ on DMR, GL, and EP (Table $3)$. The VC decreased linearly $(P<0.001) \mathrm{GL}$ and increased linearly $(P<0.001) \mathrm{DMR}$ over time. Also, there was a quadratic effect $(P<0.001)$ of VC levels on EP, with greater losses with $25 \% \mathrm{VC}$. In all storage times, there was a quadratic effect $(P=0.002)$ of VC levels on EP, with an increase followed by a reduction in EP concentrations to intermediate levels. In general, EP was reduced in the treatment with $100 \%$ of VC compared with other levels.

The DM content of silages increased linearly with the addition of VC, as a result of the higher DM content of VC compared with CSE. The DM content for treatment with $100 \%$ VC $(404 \mathrm{~g} / \mathrm{kg})$ was similar to the $450 \mathrm{~g} / \mathrm{kg}$ obtained by Molina-Alcaide et al. (2008). For the silage that contained only CSE (treatment $0 \%$ ), DM content was on average $130 \mathrm{~g} / \mathrm{kg}$, corroborating the level presented by Javorski et al. (2015). In general, $\mathrm{NH}_{3}-\mathrm{N}$ concentration was greater in silage produced from $25 \%$ CSE and $75 \% \mathrm{VC}$. In addition to increasing at ensiling, this mixture provided favourable conditions for higher proteolytic activity. The high concentration of $\mathrm{NH}_{3}-\mathrm{N}$ could be related to the Clostridium spp. counts, which were elevated concurrently. According to Baron et al. (1986), microbial and plant proteases are more active during the anaerobic phase of ensiling. Decreased $\mathrm{pH}$ favours proteolysis (Muck, 2010), resulting in increased $\mathrm{NH}_{3}-\mathrm{N}$ concentration as storage time increases. Also, reduced $\mathrm{pH}$ favoured the increase of $\mathrm{NH}_{3}-\mathrm{N}$ concentration.

Efficient microbial fermentation in silages needs at least $30 \mathrm{~g} \mathrm{WSC} / \mathrm{kg}$ and low buffering capacity (Nussio et al., 2001). Lactic acid bacteria compete with facultative anaerobic microorganisms (such as enterobacteria, yeasts and Clostridium spp.) for WSC, which are substrates for their development, with lactic acid production and, consequently, a reduction in silage $\mathrm{pH}$ (Jobim et al., 2007). The WSC concentration in the present study fluctuated between times and treatments with the inclusion of VC in silage. However, the CSE silage showed lower levels of WSC, with a maximum content of $35.1 \mathrm{~g} / \mathrm{kg}$ at day 1 of ensiling. Most of the silages in this study had the minimum WSC concentration necessary for fermentation, high LAB activity, and low $\mathrm{pH}$ values before ensiling, and might indicate low microbial activity after ensiling.

The ideal is that silages have low buffering capacity, facilitating rapid $\mathrm{pH}$ reduction, owing to the production of organic acids in the fermentation process (Siqueira et al., 2007). In all silages and times, $\mathrm{pH}$ values were within the ideal range, which varies between 3.8 and 4.2 (McDonald et al., 1991). This contributes to the conservation of silages by keeping a lesser population of undesirable bacteria, such as Clostridium and enterobacteria (Jobim et al., 2007).

The silage temperature exceeded $2^{\circ} \mathrm{C}$ above room temperature up to three days of ensiling. This may be a consequence of oxygen present in the silo, which favours undesirable fermentations (Santos et al., 2006). After seven days of evaluation, silage temperature was similar to room temperature. Thus, the $\mathrm{pH}$ increase may have favoured the proliferation of undesirable microorganisms, such as Clostridium and enterobacteria, which degrade organic compounds (McDonald et al., 1991).

The Clostridium spp. genus reduced with storage time for all treatments, showing maximum values (7.61 log CFU/g) at three days in $100 \%$ VC silages. These values corroborate the work of Javorski et al. (2015), who, when evaluating the storage of the residue from the extraction of cassava starch, obtained a maximum point at the third day of ensiling with $7.58 \mathrm{log} C F U / g$, reducing with the storage time. The reduction of Clostridium spp. may be associated with a reduction in $\mathrm{pH}$ over the ensiling time, which is responsible for controlling the proliferation of Clostridium during the fermentation process (McDonald et al., 1991). Another 
Table 1 Characteristics ( $\mathrm{g} / \mathrm{kg}$ of DM) of silages composed of cassava starch extraction and viticulture by-products at various times after ensiling (4 replicates)

\begin{tabular}{|c|c|c|c|c|c|c|c|c|c|c|c|}
\hline \multirow{2}{*}{ Variables } & \multicolumn{5}{|c|}{ Percent of viticulture by-product } & \multirow{2}{*}{ SE } & \multicolumn{5}{|c|}{$P$-values } \\
\hline & 0 & 25 & 50 & 75 & 100 & & Treatment & Time & Interaction & Linear & Quadratic \\
\hline Dry matter, $\mathrm{g} / \mathrm{kg}$ & 133 & 200 & 266 & 329 & 404 & 1.000 & $<0.001$ & 0.871 & 0.873 & $<0.001$ & 0.206 \\
\hline Organic matter, g/kg DM & 972 & 962 & 956 & 950 & 949 & 0.300 & $<0.001$ & $<0.001$ & $<0.001$ & $<0.001$ & $<0.001$ \\
\hline Day 0 & 975 & 965 & 959 & 956 & 945 & 0.700 & $<0.001$ & - & - & $<0.001$ & 0.539 \\
\hline Day 1 & 973 & 964 & 957 & 954 & 949 & 0.700 & $<0.001$ & - & - & $<0.001$ & 0.046 \\
\hline Day 3 & 970 & 961 & 951 & 952 & 955 & 0.700 & $<0.001$ & - & - & $<0.001$ & $<0.001$ \\
\hline Day 7 & 971 & 963 & 957 & 941 & 941 & 0.700 & $<0.001$ & - & - & $<0.001$ & 0.419 \\
\hline Day 15 & 972 & 961 & 956 & 952 & 951 & 0.700 & $<0.001$ & - & - & $<0.001$ & 0.002 \\
\hline Day 30 & 974 & 962 & 955 & 945 & 950 & 0.700 & $<0.001$ & - & - & $<0.001$ & $<0.001$ \\
\hline Day 60 & 971 & 962 & 958 & 950 & 954 & 0.700 & $<0.001$ & - & - & $<0.001$ & $<0.001$ \\
\hline Ammonia nitrogen, \% DM & 0.096 & 0.108 & 0.112 & 0.120 & 0.091 & 0.001 & $<0.001$ & $<0.001$ & $<0.001$ & $<0.001$ & 0.003 \\
\hline Day 0 & 0.082 & 0.058 & 0.043 & 0.026 & 0.022 & 0.001 & $<0.001$ & - & - & $<0.001$ & 0.002 \\
\hline Day 1 & 0.097 & 0.067 & 0.054 & 0.056 & 0.044 & 0.001 & $<0.001$ & - & - & $<0.001$ & 0.002 \\
\hline Day 3 & 0.143 & 0.101 & 0.091 & 0.080 & 0.064 & 0.001 & $<0.001$ & - & - & $<0.001$ & $<0.001$ \\
\hline Day 7 & 0.095 & 0.110 & 0.110 & 0.105 & 0.085 & 0.001 & $<0.001$ & - & - & 0.001 & $<0.001$ \\
\hline Day 15 & 0.087 & 0.112 & 0.135 & 0.155 & 0.114 & 0.001 & $<0.001$ & - & - & $<0.001$ & $<0.001$ \\
\hline Day 30 & 0.085 & 0.127 & 0.151 & 0.172 & 0.117 & 0.001 & $<0.001$ & - & - & $<0.001$ & $<0.001$ \\
\hline Day 60 & 0.085 & 0.182 & 0.203 & 0.247 & 0.195 & 0.001 & $<0.001$ & - & - & $<0.001$ & $<0.001$ \\
\hline Water-soluble carbohydrate, $\mathrm{g} / \mathrm{kg} \mathrm{DM}$ & 27.2 & 27.8 & 28.5 & 27.9 & 28.5 & 0.120 & 0.001 & $<0.001$ & $<0.001$ & 0.001 & 0.123 \\
\hline Day 0 & 21.5 & 28.0 & 27.4 & 20.7 & 22.1 & 0.319 & $<0.001$ & - & - & 0.004 & $<0.001$ \\
\hline Day 1 & 35.1 & 31.6 & 30.6 & 34.5 & 30.9 & 0.319 & $<0.001$ & - & - & 0.011 & 0.049 \\
\hline Day 3 & 26.3 & 27.6 & 34.1 & 36.3 & 34.5 & 0.319 & $<0.001$ & - & - & $<0.001$ & $<0.001$ \\
\hline Day 7 & 21.4 & 21.5 & 22.3 & 17.2 & 26.3 & 0.319 & $<0.001$ & - & - & 0.010 & $<0.001$ \\
\hline Day 15 & 27.5 & 27.5 & 32.6 & 32.8 & 34.0 & 0.319 & $<0.001$ & - & - & $<0.001$ & 0.270 \\
\hline Day 30 & 26.6 & 28.9 & 26.7 & 27.4 & 23.3 & 0.319 & $<0.001$ & - & - & $<0.001$ & $<0.001$ \\
\hline Day 60 & 31.9 & 29.5 & 26.0 & 26.4 & 28.2 & 0.319 & $<0.001$ & - & - & $<0.001$ & $<0.001$ \\
\hline
\end{tabular}

Equations describing treatment effects: $\mathrm{DM}=132.813+2.664 \mathrm{VC}, \mathrm{OM}=972.240-0.4399 \mathrm{VC}+0.00206 \mathrm{VC}^{2}, \mathrm{NH}_{3}-\mathrm{N}=0.09417+0.00089 \mathrm{VC}-0.000008 \mathrm{VC}{ }^{2}$, WSC $=27.560+0.09674 \mathrm{VC}$ 
Table 2 Microbial levels, $\mathrm{pH}$, temperature and buffering capacity of silages composed of cassava starch extraction and viticulture by-products at various times after ensiling (four replicates)

\begin{tabular}{|c|c|c|c|c|c|c|c|c|c|c|c|}
\hline \multirow{2}{*}{ Variables } & \multicolumn{5}{|c|}{ Percent of viticulture by-product } & \multirow[b]{2}{*}{ SE } & \multicolumn{5}{|c|}{$P$-values } \\
\hline & 0 & 25 & 50 & 75 & 100 & & Treatment & Time & Interaction & Linear & Quadratic \\
\hline Clostridium spp., log CFU g ${ }^{-1}$ & 7.00 & 6.84 & 6.85 & 6.61 & 6.63 & 0.057 & 0.189 & $<0.001$ & 0.099 & 0.016 & 0.826 \\
\hline Lactic acid bacteria, log CFU $g^{-1}$ & 5.89 & 5.91 & 5.00 & 5.65 & 4.60 & 0.148 & 0.049 & 0.107 & 0.413 & 0.014 & 0.676 \\
\hline Yeast, log CFU g ${ }^{-1}$ & 0.87 & 0.58 & 0.65 & 0.51 & 0.23 & 0.106 & 0.190 & 0.062 & 0.569 & 0.077 & 0.821 \\
\hline Enterobacteria, log CFU g ${ }^{-1}$ & 1.85 & 1.42 & 1.82 & 1.50 & 0.47 & 0.070 & $<0.001$ & $<0.001$ & $<0.001$ & $<0.001$ & 0.002 \\
\hline Day 0 & 1.91 & 2.86 & 2.34 & 1.99 & 0.71 & 0.186 & $<0.001$ & - & - & 0.011 & 0.011 \\
\hline Day 1 & 3.40 & 2.48 & 3.03 & 2.18 & 0.62 & 0.186 & $<0.001$ & - & - & $<0.001$ & 0.105 \\
\hline Day 3 & 2.57 & 2.70 & 1.54 & 1.99 & 0.00 & 0.186 & $<0.001$ & - & - & $<0.001$ & 0.110 \\
\hline Day 7 & 1.48 & 1.90 & 2.58 & 1.75 & 0.62 & 0.186 & 0.017 & - & - & 0.137 & 0.006 \\
\hline Day 15 & 1.73 & 0.00 & 1.83 & 1.13 & 1.04 & 0.186 & 0.008 & - & - & 0.836 & 0.651 \\
\hline Day 30 & 0.71 & 0.00 & 0.56 & 0.50 & 0.33 & 0.186 & 0.644 & - & - & 0.829 & 0.779 \\
\hline Day 60 & 1.12 & 0.00 & 0.87 & 0.94 & 0.00 & 0.186 & 0.103 & - & - & 0.305 & 0.782 \\
\hline $\mathrm{pH}$ & 3.56 & 3.53 & 3.64 & 3.65 & 3.50 & 0.008 & $<0.001$ & $<0.001$ & $<0.001$ & 0.999 & $<0.001$ \\
\hline Day 0 & 4.05 & 3.68 & 3.60 & 3.54 & 3.45 & 0.010 & $<0.001$ & - & - & $<0.001$ & $<0.001$ \\
\hline Day 1 & 3.88 & 3.58 & 3.48 & 3.39 & 3.31 & 0.010 & $<0.001$ & - & - & $<0.001$ & $<0.001$ \\
\hline Day 3 & 3.77 & 3.68 & 3.68 & 3.68 & 3.62 & 0.010 & $<0.001$ & - & - & $<0.001$ & 0.461 \\
\hline Day 7 & 3.50 & 3.63 & 3.83 & 3.55 & 3.46 & 0.010 & $<0.001$ & - & - & 0.022 & $<0.001$ \\
\hline Day 15 & 3.53 & 3.53 & 3.82 & 3.74 & 3.63 & 0.010 & $<0.001$ & - & - & $<0.001$ & $<0.001$ \\
\hline Day 30 & 3.17 & 3.33 & 3.58 & 3.93 & 3.64 & 0.010 & $<0.001$ & - & - & $<0.001$ & $<0.001$ \\
\hline Day 60 & 3.05 & 3.27 & 3.46 & 3.73 & 3.41 & 0.010 & $<0.001$ & - & - & $<0.001$ & $<0.001$ \\
\hline Temperature, ${ }^{\circ} \mathrm{C}$ & 26.0 & 25.7 & 25.9 & 26.0 & 26.1 & 0.016 & $<0.001$ & $<0.001$ & $<0.001$ & $<0.001$ & $<0.001$ \\
\hline Day 0 & 29.6 & 28.0 & 28.9 & 28.7 & 29.2 & 0.040 & $<0.001$ & - & - & 0.569 & $<0.001$ \\
\hline Day 1 & 25.8 & 26.0 & 25.8 & 26.1 & 26.5 & 0.040 & 0.001 & - & - & $<0.001$ & 0.021 \\
\hline Day 3 & 24.6 & 24.5 & 24.6 & 24.6 & 24.7 & 0.040 & 0.719 & - & - & 0.680 & 0.389 \\
\hline Day 7 & 25.9 & 25.9 & 25.9 & 26.2 & 26.2 & 0.040 & 0.024 & - & - & 0.032 & 0.459 \\
\hline Day 15 & 24.5 & 24.5 & 24.4 & 24.7 & 24.6 & 0.040 & 0.174 & - & - & 0.274 & 0.711 \\
\hline Day 30 & 27.5 & 27.1 & 27.3 & 27.3 & 27.3 & 0.040 & 0.057 & - & - & 0.493 & 0.219 \\
\hline Day 60 & 24.2 & 24.1 & 24.1 & 24.1 & 24.2 & 0.040 & 0.857 & - & - & 0.583 & 0.459 \\
\hline Buffering capacity, mg HCl/100 g silage & 33.5 & 42.9 & 44.8 & 47.1 & 48.2 & 1.510 & 0.042 & - & - & 0.008 & 0.130 \\
\hline
\end{tabular}

Equations describing treatment effects: clostridium $=6.9864-0.00401 \mathrm{VC}$, lactic acid bacteria $=6.0215-0.00853 \mathrm{VC}$, enterobacteria $=1.6777+0.01251 \mathrm{VC}-0.00024 \mathrm{VC}$, $\mathrm{pH}=3.4139+0.006060 \mathrm{VC}-0.00005 \mathrm{VC}^{2}$, temperature $=25.9191-0.00520 \mathrm{VC}+0.000071 \mathrm{VC}^{2}$, buffering capacity $=37.519+0.1326 \mathrm{VC}$ 
Table 3 Dry matter recovery, gas losses and effluent production from silages composed of cassava starch extraction and viticulture by-products at various times after ensiling (four replicates)

\begin{tabular}{|c|c|c|c|c|c|c|c|c|c|c|c|}
\hline \multirow{2}{*}{ Variables } & \multicolumn{5}{|c|}{ Percent of viticulture by-product } & \multirow{2}{*}{ SE } & \multicolumn{5}{|c|}{$P$-values } \\
\hline & 0 & 25 & 50 & 75 & 100 & & Treatment & Time & Interaction & Linear & Quadratic \\
\hline Dry matter recovery, \% & 94.5 & 95.8 & 96.6 & 98.9 & 99.6 & 0.200 & $<0.001$ & $<0.001$ & $<0.001$ & $<0.001$ & 0.849 \\
\hline D1 & 100.0 & 100.0 & 100.0 & 100 & 99.9 & 0.540 & 0.997 & - & - & 0.950 & 0.954 \\
\hline D3 & 96.9 & 98.1 & 97.7 & 99.6 & 100.0 & 0.540 & 0.070 & - & - & 0.092 & 0.908 \\
\hline D7 & 95.4 & 96.0 & 97.2 & 98.6 & 99.5 & 0.540 & 0.003 & - & - & 0.025 & 0.905 \\
\hline D15 & 90.5 & 95.5 & 96.3 & 98.7 & 99.4 & 0.540 & $<0.001$ & - & - & $<0.001$ & 0.170 \\
\hline D30 & 94.5 & 91.4 & 93.1 & 98.5 & 99.4 & 0.540 & $<0.001$ & - & - & 0.001 & 0.023 \\
\hline $\mathrm{D} 60$ & 89.8 & 93.7 & 95.1 & 97.9 & 99.4 & 0.540 & $<0.001$ & - & - & $<0.001$ & 0.494 \\
\hline Gas losses, \% & 0.404 & 0.209 & 0.130 & 0.034 & 0.010 & 0.012 & $<0.001$ & $<0.001$ & $<0.001$ & $<0.001$ & 0.016 \\
\hline D1 & $<0.001$ & $<0.001$ & $<0.001$ & $<0.001$ & 0.004 & 0.032 & 0.999 & - & - & 0.981 & 0.982 \\
\hline D3 & 0.238 & 0.096 & 0.085 & 0.011 & $<0.001$ & 0.032 & 0.056 & - & - & 0.072 & 0.522 \\
\hline D7 & 0.361 & 0.206 & 0.106 & 0.044 & 0.013 & 0.032 & 0.000 & - & - & 0.009 & 0.359 \\
\hline D15 & 0.686 & 0.225 & 0.140 & 0.041 & 0.014 & 0.032 & $<0.001$ & - & - & $<0.001$ & 0.010 \\
\hline D30 & 0.415 & 0.416 & 0.265 & 0.047 & 0.014 & 0.032 & $<0.001$ & - & - & 0.001 & 0.660 \\
\hline D60 & 0.725 & 0.310 & 0.181 & 0.065 & 0.015 & 0.032 & $<0.001$ & - & - & $<0.001$ & 0.024 \\
\hline Effluent production, \% & 37.1 & 37.5 & 35.0 & 31.8 & 5.1 & 0.374 & $<0.001$ & $<0.001$ & 0.004 & $<0.001$ & $<0.001$ \\
\hline $\mathrm{D} 1$ & 32.2 & 33.1 & 23.9 & 18.2 & 2.3 & 0.990 & $<0.001$ & - & - & $<0.001$ & 0.002 \\
\hline D3 & 39.8 & 38.2 & 38.4 & 33.5 & 11.0 & 0.990 & $<0.001$ & - & - & $<0.001$ & $<0.001$ \\
\hline D7 & 36.0 & 38.2 & 39.0 & 35.1 & 3.3 & 0.990 & $<0.001$ & - & - & $<0.001$ & $<0.001$ \\
\hline D15 & 37.0 & 37.6 & 36.2 & 31.8 & 4.3 & 0.990 & $<0.001$ & - & - & $<0.001$ & $<0.001$ \\
\hline D30 & 39.7 & 35.9 & 32.1 & 32.9 & 5.7 & 0.990 & $<0.001$ & - & - & $<0.001$ & $<0.001$ \\
\hline $\mathrm{D} 60$ & 38.2 & 41.9 & 40.5 & 39.2 & 3.4 & 0.990 & $<0.001$ & - & - & $<0.001$ & $<0.001$ \\
\hline
\end{tabular}

DMR: dry matter recovery; GL: gas losses; $\mathrm{EP}$ : effluent production; equations describing treatment effects: $\mathrm{DMR}=94.9346+0.04675 \mathrm{VC}$, GL $=0.3903-$ $0.00748 \mathrm{VC}+0.000037 \mathrm{VC}^{2}, \mathrm{EP}=36.054+0.2057 \mathrm{VC}-0.00504 \mathrm{VC}^{2}$ 
factor that is correlated with the inhibition of these bacteria is the increase in osmotic pressure, that is, lower water activity and inhibition of growth of these microorganisms (Muck, 1988). Both factors are present with VC addition in CSE silages.

Values above $8.0 \log \mathrm{CFU} / \mathrm{g}$ of $\mathrm{LAB}$ are favourable to rapid reduction of $\mathrm{pH}$ and improve the conservation of ensiled material (McDonald et al., 1991). However, in this study, the observed pH was lower than recommended for the LAB population, but this smaller population did not affect the $\mathrm{pH}$ reduction.

The low yeast population may be associated with the absence of oxygen for its proliferation and other microorganisms dominating the fermentation. In anaerobiosis, the yeasts ferment sugars in ethanol and $\mathrm{CO}_{2}$. In aerobiosis, they degrade lactic acid in $\mathrm{CO}_{2}$ and $\mathrm{H}_{2} \mathrm{O}$, raising the $\mathrm{pH}$ of the ensiled mass (Stefanie et al., 2000). When competing with $L A B$ for the substrate at the beginning of the fermentation process, they can transform it into ethanol, affecting conservation and causing losses of DM and energy (Jobim \& Gonçalves, 2003). Yeasts are found in greater amounts in silages with a longer aerobic initial phase (Jobim \& Gonçalves, 2003). In the present study, the incidence of yeasts at various times and treatments was lower than those considered harmful to the silage quality, that is, lower than $5.0 \mathrm{log}$ CFU/g (Woolford, 1990).

Enterobacteria has activities related to the $\mathrm{pH}$ of the ensiled material, which remained below 4.2 at all storage times. Enterobacteria can be inhibited when pH is below 4.5 (Stefanie et al., 2000), which explains the low proliferation of this microorganism with the addition of VC in the present study.

The increase of VC in the silages improved DMR, and it reduced with the ensiling time. Silages with the highest percentage of CSE had higher GL and EP over the ensiling time, which can be explained by the lower DM content of CSE. Treatments $25 \%$ and $50 \% \mathrm{VC}$ had an increase in GL up to 30 days of storage, and then there was a reduction in this variable. The increase in GL up to 30 days of ensiling may have been caused by the action of heterofermentative bacteria that increased losses by gases in silages (Pacheco et al., 2014). Mota et al. (2011) evaluated the silage of the aerial part of four varieties of cassava and observed that, over the ensiled time, GL and EP increase. These losses can be reduced by ensiling feeds with a minimum DM content of $300 \mathrm{~g} / \mathrm{kg}$ (McDonald et al., 1991).

\section{Conclusion}

The addition of VC to CSE by-product silage increased the content of dry matter and soluble carbohydrates and reduced the fermentative losses of silage. Moreover, $\mathrm{pH}$ values in silages that contained VC favoured their conservation and inhibited the proliferation of yeasts. However, the population of Clostridium spp. was high in these silages. Silages that are composed of CSE and VC mixtures can be stored up to 60 days.

\section{Acknowledgments}

The authors would like to thank the Brazilian National Council for Scientific and Technological Development (CNPq) for the grant scholarship and Coordination for the Improvement of Higher Education Personnel (CAPES PROCAD no 88881.068464/2014-01) for their financial support.

\section{Authors' Contributions}

CRS and MAZ were in charge of project design and writing of the manuscript. CRS, DG, AF, ASA and RCRT were in charge of project implementation. All co-authors participated in results, statistics and interpretation of the study.

\section{Conflict of Interest Declaration}

The authors declare no conflict of interest.

\section{References}

AOAC, 2000. Official methods of analysis. 17th ed. Association of Official Analytical Chemists, Inc., Maryland, USA.

Baron, V.S., Stevenson, K.R. \& Buchanan-Smith, J.G., 1986. Proteolysis and fermentation of grain-corn ensiled at several moisture levels and under several simulated storage methods. Can. J. Anim. Sci. 66, 451461. https://doi.org/10.4141/cjas86-047

Čolović, D., Rakita, S., Banjac, V., Đuragić, O. \& Čabarkapa I., 2019. Plant food by-products as feed: Characteristics, possibilities, environmental benefits, and negative sides. Food Rev. Int. 35, 363-389. https://doi.org/10.1080/87559129.2019.1573431

Cherney, J.H. \& Cherney, D.J.R., 2003. Assessing silage quality. In: D.R. Buxton., R.E. Muck \& J.H. Harrison (editors). Silage science and technology. American Society of Agronomy, Madison, Wisconsin, Pp. 141-198.

Correddu, F., Nudda, A., Battacone, G., Boe, R., Francesconi, A.H.D. \& Pulina G., 2015. Effects of grape seed supplementation, alone or associated with linseed, on ruminal metabolism in Sarda dairy sheep. Anim. Feed Sci. Technol. 199, 61-72. https://dx.doi.org/10.1016/j.anifeedsci.2014.11.002

Dubois, M., Gilles, K.A., Hamilton, J.K., Rebers, P.T. \& Smith, F., 1956. Colorimetric method for determination of sugars and related substances. Anal. Chem. 28, 350-356. https://doi.org/10.1021/ac60111a017

Fenner, H., 1965. Method for determining total volatile bases in rumen fluid by steam distillation. J. Dairy Sci. 48, 249251. DOI: $10.3168 /$ jds.S0022-0302(65)88206-6 
Fernandes, T., Zambom, M.A., Castagnara, D.D., Tinini, R.C.R., Cruz, E.A., Eckstein, E.I. \& Lange M.J., 2016. Nutritional assessment of waste of cassava starch extraction dried in cattle feed. Sem: Ciênc. Agrár. 37, 26532664. DOI: 10.5433/1679-0359.2016v37n4Supl1p2653

Gonçalves, J.A.G., Zambom, M.A., Fernandes, T., Mesquita, E.E., Schimidt, E., Javorski, C.R. \& Castagnara, D.D., 2014. Chemical composition and profile of the fermentation of cassava starch by-products silage. Biosci. J. 30, 502-511. (in Portuguese, English abstract).

Jasko, A.C., Andrade, J.D., Campos, P.F.D., Padilha, L., Pauli, R.B.D., Quast, L.B. \& Demiate, I.M., 2011. Physicochemical characterization of cassava bagasse in natura and after hydrolytic treatment. Rev. Bras. Tecnol. Agro. 5, 427-441. (in Portuguese, English abstract).

Javorski, C.R., Zambom, M.A., Pozza, M.S.S., Fernandes, T., Castagnara, D.D., Paladini, S. \& Neres, M.A., 2015. Stoking residue from extraction of cassava starch without the use of storage technologies. Ciênc. Rural. 45, 405411. https://doi.org/10.1590/0103-8478cr20131602

Jobim, C.C. \& Gonçalves, G.D., 2003. Preserved fodder microbiology. Ruminants in ruminant production: Feed value of fodder (in Portuguese, English abstract). Jaboticabal: Funep.

Jobim, C.C., Nussio, L.G., Reis, R.A. \& Schmidt, P., 2007. Methodological advances in evaluation of preserved forage quality. Rev. Bras. Zootecn. 36, 101-119. https://doi.org/10.1590/S1516-35982007001000013

Kalli, E., Lappa, I., Bouchagier, P., Tarantilis, P.A. \& Skotti, E., 2018. Novel application and industrial exploitation of winery by-products. Bioresour. Bioprocess., 5, 46. https://doi.org/10.1186/s40643-018-0232-6

Ke, W.C., Yang, F.Y., Undersander, D.J. \& Guo, X.S., 2015. Fermentation characteristics, aerobic stability, proteolysis and lipid composition of alfalfa silage ensiled with apple or grape pomace. Anim. Feed Sci. Technol. 202, 12-19. https://doi.org/10.1016/j.anifeedsci.2015.01.009

Massaro Junior, F.L., Bumbieris Junior, V.H., Zanin, E., Silva, L.D.F., Galbeiro, S., Pereira, E.S., Neumann, M. \& Mizubuti, I.Y., 2020. Effect of storage time and use of additives on the quality of grape pomace silages. J Food Process Preserv. 00:e14373. DOI:10.1111/jfpp.14373

McDonald, P.J., Henderson, A.R. \& Heron, S.J.E., 1991. The biochemistry of silage. Second edition. Chalcombe, Marlow, England. ISBN 0948617225. 340 pp.

Molina-Alcaide, E., Moumen, A. \& Martín-García, I., 2008. By-products from viticulture and the wine industry: Potential as sources of nutrients for ruminants. J. Sci. Food Agric. 88, 597-604. DOI: 10.1002/jsfa.3123

Mota, A.D.S., Rocha Júnior, V.R., Souza, A.D., Reis, S.D., Tomich, T.R., Caldeira, L.A. \& Costa, M.D., 2011. Fermentation profile and losses in the ensilage of different fractions of the aerial part from four cassava varieties. Rev. Bras. Zootecn. 40, 1466-1473. DOI: 10.1590/S1516-35982011000700010

Muck, R.E., 2010. Silage microbiology and its control through additives. Rev. Bras. Zootec. 39, $183-191$. https://doi.org/10.1590/S1516-35982010001300021

Muck, R.E., 1988. Factors influencing silage quality and their implications for management. J. Dairy Sci. 71, 2992-3002. https://doi.org/10.3168/jds.S0022-0302(88)79897-5

Nussio, L.G., Simas, J.E.C. \& Lima, M.L.M., 2001. Determination of the ideal maturity point for corn harvesting for silage. Corn for silage. FEALQ, Piracicaba. (in Portuguese, English abstract).

Pacheco, F.W., Carneiro, M.S.S., Pinto, A.P., Edvan, R.L., Arruda, P.C.L. \& Carmo, A.B.R., 2014. Fermentation losses of elephant grass (Pennisetum purpureum Schum.) silage with increasing levels of (Gliricidia sepium) hay. Acta Vet. Bras. 8, 155-162.

Playne, M.J. \& McDonald, P., 1966. The buffering constituents of herbage and of silage. J. Sci. Food Agric. 17, $264-268$. DOI: $10.1002 / J S F A .2740170609$

Santos, E.M., Zanine, A.M. \& Oliveira, J.S., 2006. Production of silage of grass tropical. Rev. Elect. Vet. 7, 1-16. (in Portuguese, English abstract).

Santos, N.W., Santos, G.T.D., Silva-Kazama, D.C., Grande, P.A., Pintro, P.M., De Marchi, F.E. \& Petit, H.V., 2014. Production, composition and antioxidants in milk of dairy cows fed diets containing soybean oil and grape residue silage. Livest. Sci. 159, 37-45.

Sebrae, 2008. Estudo de mercado sobre a mandioca (farinha e fécula). Serviço de apoio às micro e pequenas empresas. http://atividaderural.com.br/artigos/5602f3e181880.pdf

Silva, N., Junqueira, V.C.A. \& Silveira, N.F.A., 1997. Manual of microbiological food analysis methods (in Portuguese). Livraria Varela, São Paulo.

Siqueira, G.R., Reis, R.A., Schocken-Iturrino, R.P., Bernardes, T.F., Pires, A.J.V., Roth, M.D.T.P. \& Roth, A.P.D.T.P., 2007. Chemical and bacterial additives association on the sugar cane ensilage. Rev. Bras. Zootecn. 36, 789-798. (in Portuguese, English abstract) https://doi.org/10.1590/S1516-35982007000400006

Stefanie, J.W.H., Elfeink, O., Driehuis, F., Gottschal, J.C. \& Spoelstra, S.F., 2000. Silage fermentation process and their manipulation. In: Silage making in the tropics with particular emphasis on smallholders. Proc. FAO Electronic Conference on Tropical Silage. Rome Italy. Pages 17-30.

Woolford, M.K., 1990. The detrimental effect of air on silage. J. Appl. Bacteriol. 68, 101-116. https://doi.org/10.1111/j.1365-2672.1990.tb02554.x

Zambom, M., Fernandes, T., Soares, M.S.S.P., Castagnara, D.D., Neres, M.A, Javorski, C.R. \& Cruz, E.A., 2014. Characteristics from wet residue silage of cassava starch with different levels of urea added. Arch. Zootecn. 63, 677-688. (in Portuguese, English abstract).

Zambom, M., Fernandes, T., Schmidt, E.L., Gonçalves, J.A.G, Soares, M.S.S.P., Javorski, CR. \& Tinini, RCR., 2015. Silage of residue from the extraction of cassava starch in diets from lactating Holstein cows. Sem: Ciênc. Agrár. 36, 1701-1712. 